\title{
Penerapan Metode Kombinasi Algoritma Genetika dan Tabu Search dalam Optimasi Alokasi Kapal Peti Kemas (Studi Kasus : PT. XYZ)
}

\author{
Novian Tiandini dan Wiwik Anggraeni \\ Jurusan Sistem Informasi, Fakultas Teknologi Informasi, Institut Teknologi Sepuluh Nopember (ITS) \\ Jl. Arief Rahman Hakim, Surabaya 60111 Indonesia \\ e-mail:wiwik@is.its.ac.id
}

\begin{abstract}
Abstrak- Perkembangan perdagangan global menyebabkan penggunaan jasa transportasi menjadi bagian yang sangat penting dalam pendistribusian barang. Salah satunya yaitu jasa transportasi laut atau jasa pelayaran. Dengan terus berkembangnya jasa pelayaran, maka perlu adanya perencanaan dan keputusan-keputusan yang tepat dalam pengalokasian kapal yang akan digunakan dalam proses pengiriman barang. Oleh karena itu dalam penelitian ini akan dilakukan optimalisasi alokasi kapal pada PT.XYZ dengan tujuan memaksimalkan profit dan memaksimalkan kapasitas menggunakan metode kombinasi algoritma genrtika dan tabu search. Penggunaan metode kombinasi algoritma genetika dan tabu search pada pengalokasian kapal bertujuan untuk menemukan solusi yang optimum dalam mengalokasikan kapal. Berdasarkan perbandingan antara metode algortima genetika (GA) dan metode kombinasi algoritma genetika dan tabu search (GA-TS), diperoleh hasil profit dan muatan yang lebih optimal ketika menggunakan metode GA-TS dengan peningkatan profit sebesar $69 \%$ dan peningkatan load factor sebesar $14 \%$. Peningkatan profit dan load factor juga ditunjukkan ketika dilakukan perbandingan antara kondisi pada perusahaan sebelum menerapkan GA-TS dan sesudah menerapkan GA-TS. Metode GA-TS memiliki profit dengan peningkatan lebih dari $100 \%$ dan peningkatan load factor sebesar $38 \%$ dibanding pada kondisi perusahaan. Sehingga berdasarkan hal ini, implementasi algoritma genetika dan tabu search dapat menjadi solusi bagi perusahaan dan membantu perusahaan dalam membuat perencanaan pengalokasian kapal..
\end{abstract}

Kata Kunci- Optimasi, Alokasi, Jasa Pelayaran, Kapal Peti Kemas, Algoritma Genetika, Tabu Seacrh.

\section{PENDAHULUAN}

$\mathrm{I}$ NDONESIA merupakan negara kepulauan terbesar di dunia yang terdiri dari 17.508 pulau dan memiliki luas wilayah laut yang sangat luas yaitu 7,900,000 km2 [1]. Letak geografis Indonesia yang strategis serta besarnya potensi ekonomi kelautan dapat memberi kesempatan yang besar bagi Indonesia untuk mempercepat terwujudnya kemandirian ekonomi nasional. Pelayaran atau angkutan laut adalah salah satu jasa yang memiliki peranan penting dalam mendorong dan membantu menghadapi perubahan dan perkembangan ekonomi nasiaonal yaitu melalui perdagangan global. Saat ini banyak perusahaan - perusahaan produsen yang menggunakan jasa pelayaran untuk menyalurkan barang tersebut dari produsen sampai ke konsumen atau pemakai industri.

Sehingga dengan terus berkembangnya jasa pelayaran dan tanggung jawab yang dimiliki, maka perlu adanya perencanaan dan keputusan-keputusan yang tepat dalam menyediakan jasa pelayaran agar perusahaan penyedia jasa dapat terus bersaing dan memeberikan pelayanan yang terbaik. Oleh karena itu dalam penelitian ini akan dilakukan optimalisasi alokasi kapal dengan tujuan memaksimalkan pendapatan dan memaksimalkan kapasitas kapal. Sehingga perlu adanya penelitian dengan menggunakan kombinasi algoritma genetika dan tabu search sebagai sebuah metode yang dapat membantu dalam menentukan perencanaan pengalokasian kapal terbaik berdasarkan tujuan yang ingin di capai.

Metode yang akan digunakan pada penelitian ini yaitu metode kombinasi algoritma genetika dan tabu search. Algoritma genetika yang dikembangkan oleh Goldberg adalah algoritma komputasi yang diinspirasi teori evolusi Darwin yang menyatakan bahwa kelangsungan hidup suatu makhluk dipengaruhi aturan "yang kuat adalah yang menang" [3]. Kelebihan metode algoritma genetika dibandingkan dengan metode optimasi lainnya adalah algoritma genetika merupakan algoritma berbasis populasi yang memungkinkan digunakan pada optimasi masalah dengan ruang pencarian (search space) yang sangat luas dan kompleks dan metode ini bisa diimplementasikan pada berbagai macam data seperti data yang dibangkitkan secara numerik atau menggunakan fungsi analitis [4]. Namun algoritma genetika juga memiliki kekurangan, yaitu dibutuhkan iterasi yang lebih lama dan algoritma genetika cenderung terjebak ke dalam solusi local optima [5], [6]. Sehingga untuk menutupi kekurangan dalam mengidentifikasi solusi local optima digunakan metode tabu search untuk menghindari lingkaran di bidang solusi yang sama, selain itu tabu search memiliki kecepatan eksekusi lebih tinggi dari pada algoritma genetika karena tabu search tidak kembali pada solusi yang sudah dieksplorasi [6]. 


\section{TINJAUAN PUSTAKA}

\section{A. Penelitian Sebelumnya}

Penelitian yang dilakukan oleh Gautam Garai, B.B. Chaudhurii [6]. pada tahun 2013 dengan judul A novel hybrid genetic algorithm with Tabu search for optimizing multidimensional functions and point pattern recognition Preference ini terkait pendekatan evolusioner hybrid baru untuk mengoptimalkan fungsi matematika dan masalah Point Pattern Recognition (PPR). Metode yang diusulkan menggabungkan algoritma genetika dan pencarian tabu. Pendekatan ini dapat mencapai global optimum atau nearglobal dalam ruang dimensi yang tinggi. Penelitian sebelumnya juga dilakukan oleh Dung-Ying Lin dan Hui-Yen Liu [9] pada tahun 2011 dengan judul Combined ship allocation, routing and freight assignment in tramp shipping dimana menggunakan pendekatan metode algoritma genetika untuk mengalokasikan kapal tramp dengan mempertimbangkan rute dan penugasan kapal.

\section{B. Optimasi}

Persoalan optimasi (optimization problem) adalah persoalan yang menunt[3]ut pencarian solusi optimum [3]. Persoalan optimasi dibagi menjadi dua macam, yaitu maksimasi (maximization) dan minimasi (minimization). Ada dua metode dalam penyelesaian masalah optimasi, yaitu (1) Metode Konvensional yang diterapkan dengan menggunakan perhitungan matematika murni atau secara biasa. Ada beberapa metode konvensional yang sering digunakan untuk menyelesaikan masalah optimasi, diantaranya: algoritma Djikstra, algoritma Floyd-Warshall, dan algoritma BellmanFord. (2) Metode Heuristik salah satu dari bidang kecerdasan buatan yang digunakan untuk menyelesaikan masalah optimasi. Terdapat beberapa algoritma dari metode heuristik yang sering digunakan dalam permasalahan optimasi, diantaranya adalah algoritma genetika, algoritma pencarian tabu, jaringan saraf tiruan, algoritma semut dan lain-lain [10]

\section{Alokasi Sumber Daya}

Resource allocation problem (RAP) adalah proses mengalokasikan sumber daya di antara berbagai proyek atau unit bisnis untuk memaksimalkan keuntungan atau meminimalkan biaya. Proses RAP berusaha untuk menemukan alokasi optimal dari jumlah sumber daya yang terabatas dengan sejumlah tugas untuk mengoptimalkan tujuan mereka dengan batasan atau kendala yang diberikan. Sumber daya mungkin berupa orang, aset, bahan, atau modal yang dapat digunakan untuk mencapai tujuan [12]

\section{Jasa Pelayarn}

Usaha pelayaran adalah kegiatan yang menawarkan jasa pengangkutan melalui laut dalam bentuk pengankutan barang dari pelabuhan pemuatan sampai ke pelabuhan bongkar/ tujuan dalam keadaan baik atau sesuai dengan perjanjian antara pengangkut dan penjual atau penerima barang [13].

\section{E. Algoritma Genetika}

Algoritma genetika merupakan salah satu metode untuk menentukan optimalisasi atas dasar Teori Darwin. Langkah prosedur algoritma ini diawali dengan menentukan suatu set solusi potensial dan melakukan perubahan dengan beberapa 
perulangan (iterasi) dengan algoritma genetika untuk menghasilkan solusi terbaik. Set solusi potensial ini ditetapkan diawal dan disebut dengan kromosom. Kromosom ini dibentuk secara random berupa susunan angka binary yang digenerate dan dipilih. Keseluruhan set dari kromosom yang diobservasi mewakili suatu populasi [16].

\section{F. Tabu Search}

Tabu Search adalah local search meta heuristik yang dapat digunakan untuk memecahkan masalah optimasi kombinatorial. Jika dibandingkan dengan teknik local search hill climbing atau pencarian local hill climbing, itu cenderung ke dalam solusi local optim. Tabu search memiliki kecepatan eksekusi lebih tinggi dari pada algoritma genetika karena tabu search tidak kembali pada solusi yang sudah dieksplorasi, mengingat bahwa adalah tabu[6]. Solusi yang sudah ada sebelumnya dicegah dengan menggunakan memori yang disebut dengan Tabu List. Tabu List yang ada pada tabu search digunakan untuk menyimpan sekumpulan solusi yang baru saja dievaluasi. Selama proses optimasi, pada setiap iterasi, solusi yang akan dievaluasi akan dicocokkan terlebih dahulu dengan isi tabu list. Apabila solusi tersebut sudah ada pada pada tabu list, maka solusi tersebut tidak akan dievaluasi lagi pada iterasi berikutnya. Apabila sudah tidak ada lagi solusi yang tidak menjadi anggota tabu list, maka nilai terbaik yang baru saja diperoleh merupakan solusi yang sebenarnya [5].

\section{G. Standard Deviasi}

Standar deviasi merupakan ukuran keragaman atau variasi data statistik yang biasanya digunakan, standar deviasi juga biasa disebut simpangan baku yang merupakan akar kuadrrat dari varian. Tujuan dari penghitungan standar deviasi adalah untuk mengetahui keragaman kelompok data. Berikut merupakan rumusan dari standar deviasi:

$s=\sqrt{\frac{n \sum_{n_{1}} x_{i}^{4}-\left(\sum_{n_{1}} x_{1}\right)^{2}}{n(n-1)}}$

Dari rumus tersebut, $\mathrm{s}$ merupakan standar deviasi (simpangan baku), Xi merupakan nilai x ke i, $\bar{x}$ merupakan rata-rata dari $\mathrm{X}$, dan $\mathrm{n}$ merupakan ukuran sampel dimana pada standar deviasi yang memiliki nilai kecil menunjukkan bahwa data-data pada himpunan tersebut mendekati atau berada pada sekitar rata-rata nilai himpunan [16].

\section{H. Error Variance}

Untuk pengukuran tingkat validitas dari perhitungan dibutuhkan suatu indikator yang dapat menunjukkan tingkat kesalahan atau error pada suatu model yang sudah ditetapkan, sehingga dalam mengukur tingkat kesalahan digunakan error variance. Model dapat dikatakan valid apabila nilai $\mathrm{E} \leq 30 \%$. Berikut merupakan perumusan dari error variance [17]:

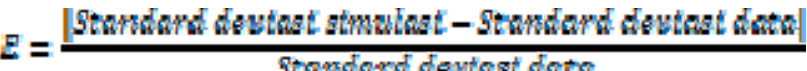

\section{METODOLOGI}

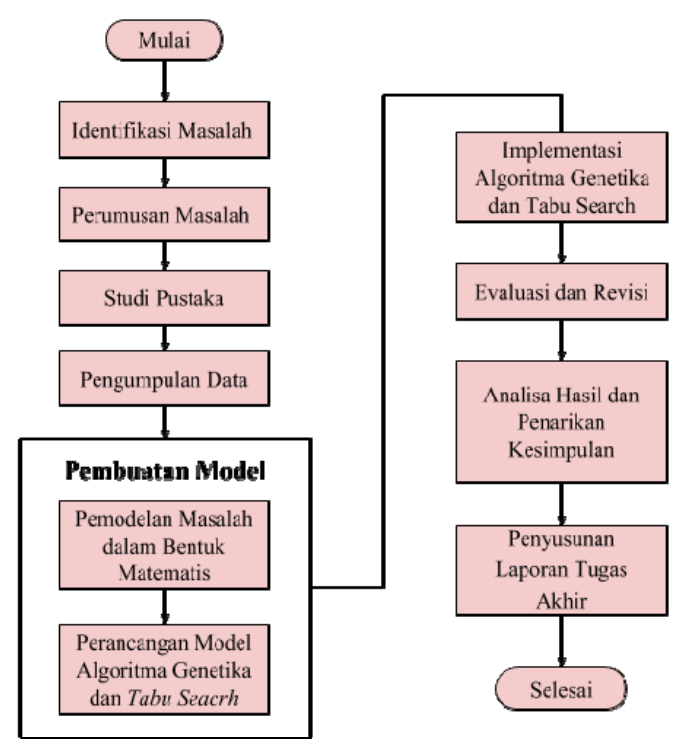

Gambar 1. Diagram Alur Penelitian

\section{A. Identifikasi Masalah}

Dalam tahap identifikasi masalah, dilakukan studi literature dengan mencari jurnal, paper, studi atau penelitian-penelitian terkait mengenai permasalahan optimasi alokasi khususnya alokasi sumberdaya sehingga dapat ditentukan metode penyelesaian yang sesuai.

\section{B. Perumusan Masalah}

Dalam memulai melakukan penelitian studi ini perlu dilakukan perumusan masalah untuk menentukkan tujuan yang akan di capai dan faktor faktor yang dapat mempengaruhi serta penggunaan metode penyelesaian yang akan digunakan

\section{Studi Pustaka}

Studi pustaka dapat dilakukan dengan cara mengumpulkan referensi, mempelajari dan memahami serta mengutip konsep atau teori dari sejumlah literature seperti buku, penelitian sebelumnya dan dokumen terkait. Pada tahapan ini dapat dilakukan dengan berfokus pada metode yang akan digunakan dalam menyelesaikan masalah yang berkaitan dengan alokasi yaitu metode algoritma genetika.

\section{Pengumpulan Data}

Pada tahap ini dilakukan proses pengumpulan data yang dibutuhkan sebagai masukan dalam penyelesaian studi ini. Data di ambil dari perusahaan penyedia jasa pelayaran yaitu salah satu perusahaan pelayaran di Surabaya. Metode pengambilan data yang digunakan yaitu metode pengumpulan bahan dokumen dan wawancara. Pengambilan data dilakukan dengan permohonan kepada perusahaan dengan keterangan person in charge (PIC) sebagai pendukung.

\section{E. Pemodelan Masalah dalam Bentuk Matematis}

Sebelum memulai perancangan model kombinasi algoritma genetika dan tabu search, terlebih dahulu dilakukan 
pemodelan matematis dari permasalahan atau studi kasus yang ada. Pada studi digunakan studi kasus pada perusahaan pelayaran yaitu mengenai alokasi kapal peti kemas dengan tujuan memaksimalkan pendapatan dan memaksimalkan muatan kapal. Muatan kapal yang dimaksud pada studi ini berupa satuan container.

1) Penentuan Variabel

Variabel Input

demand $\quad=$ jumlah permintaan container yang harus dikirim menggunakan kapal i ke lokasi j.

$\mathrm{P}_{\mathrm{ij}} \quad=$ tarif/harga sewa perkontainer kapal i ke lokasi j

$\mathrm{Cap}_{\mathrm{i}} \quad=$ kapasitas muat kapal i

Variabel Output

$\mathrm{X}_{\mathrm{ijk}} \quad=$ jumlah container yang dikirim menggunakan kapal i ke lokasi j pada perjalanan ke-k.

Bestprofit = keuntungan maksimal perusahaan berdasarkan kromosom terpilih

2) Perumusan Fungsi Tujuan

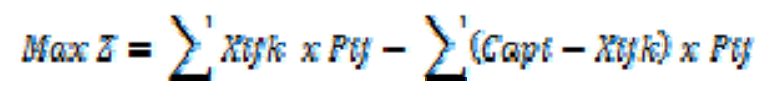

3) Perumusan Batasan

a. Batasan Total Muatan yang di Kirim

Batasan ini digunakan untuk membatasi total kontainer yang dikirim ke masing-masng tujuan agar sesuai dengan permintaan. Total kontainer yang dikirimkan oleh semua kapal yang menuju tujuan $\mathrm{j}$ tidak boleh lebih atau kurang dari jumlah permintaan pada tujuan $\mathrm{j}$.

- Jika total muatan container yang ada pada lokasi $\mathrm{j}$ kurang dari permintaan, maka kapal selanjutnya yang melakukan pengiriman ke tujuan tersebut akan membawa muatan dari hasil random dengan batas bawah 0 sampai batas kapasitas maksimal kapal.

Jika

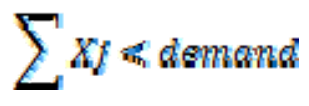

maka

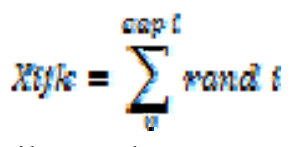

- Jika hasil random tersebut di atas ditambah akumulasi total container yang sudah ada pada lokasi j lebih dari permintaan, maka kapal yang akan mengirimkan barang menuju lokasi tersebut akan membawa muatan berjumlah selisih antara jumlah permintaan dan total container yang sudah berada pada lokasi $\mathrm{j}$.

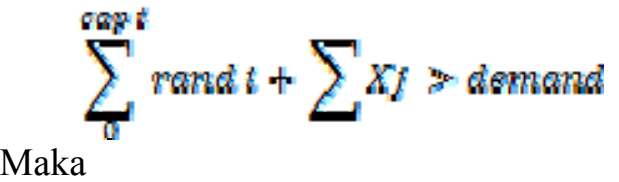

$$
\text { Xtw }=\text { demwand }-X
$$

- Jika total barang yang ada di lokasi j sama dengan permintaan atau demand maka muatan kapal akan diberi nilai sama dengan 0 karena permintaan sudah terpenuhi.

Jika

\section{$X=$ demwand}

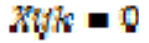

b. Batasan Jumlah Muatan Kapal

Batasan ini digunakan untuk membatasi jumlah muatan yang di bawa masing-masing kapal i menuju lokasi j tidak boleh melebihi kapasitas maksimum kapal. Sehingga dapat di tuliskan dalam bentuk matematis berikut :

\section{Wetk sap}

c. Batasan Berapa Kali Kapal Dapat Melakukan Pengiriman Batasan ini digunakan untuk membatasi jumlah atau frekuensi kapal i dalam melakukan pengiriman ke lokasi j. Sehingga tidak akan terjadi pengiriman dengan kapal yang sama terus menerus. Kapal i dapat melakukan pengiriman ke lokasi j maksimal sebanyak BB. Dimana BB dihasilkan dari perhitungan jumlah permintaan lokasi j dibagi dengan kapasitas maksimal kapal i. Berikut adalah bentuk matematisnya :

$$
B B=\frac{\text { Fropmontwan perbwhn }}{\operatorname{Cop} !}
$$

\section{F. Perancangan Algoritma Genetika dan Tabu Seacrh}

Pada tahap desain algoritma genetika dan tabu seacrh, akan di lakukan proses penyelesaian dengan menggunakan algoritma genetika terlebih dahulu baru kemudian metode tabu search diterapkan menggunakan perangkat lunak MATLAB R2013a. Berdasarkan studi kasus pada studi ini dilakukan implementasi menggunakan algoritma genetika dengan nilai kontinyus. Berikut adalah flowchart atau diagram alir proses algoritma genetika dan tabu search dalam pembuatan program MATLAB. 


\begin{tabular}{cccc}
\hline $\begin{array}{c}\text { Total Aktual } \\
\text { Profit (Rp) }\end{array}$ & $\begin{array}{c}\text { Total } \\
\text { Opportunity } \\
\text { Cost (Rp) }\end{array}$ & $\begin{array}{c}\text { Total Net Profit } \\
\text { (Rp) }\end{array}$ & $\begin{array}{c}\text { Waktu } \\
\text { Komputasi } \\
\text { (detik) }\end{array}$ \\
\hline & & & \\
$25,620,100,000$ & $10,936,100,000$ & $14,684,000,000$ & $115.323 \mathrm{~s}$ \\
\hline
\end{tabular}

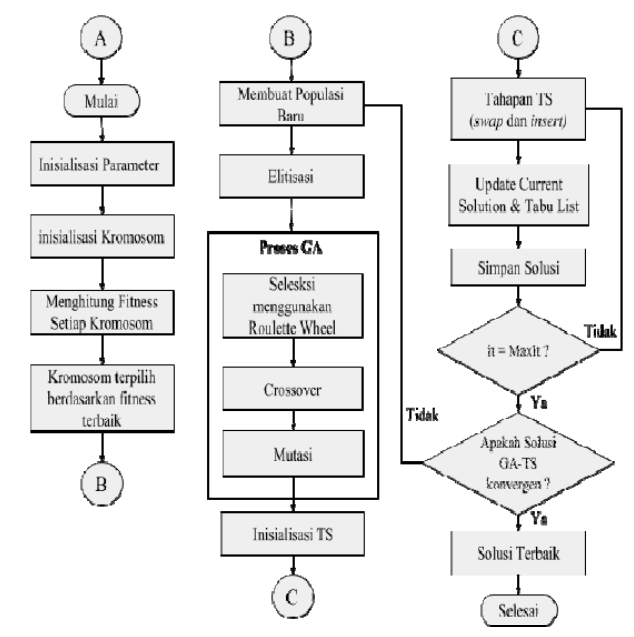

Gambar 2. Flowchart GA-TS

\section{ANALISIS DAN PEMBAHASAN}

\section{A. Skenario Uji Coba}

Pada pengerjaan studi ini akan dibutuhkan skenario uji coba dalam mengetahui hasil algoritma genetika yang paling optimal. Skenario ini nantinya akan berpengaruh pada muatan yang akan dibawa masing-masing kapal untuk mengirimkan barang. Berikut merupakan skenario yang dibuat dalam uji coba:.

a. Perbandingan profit yang diperoleh berdasarkan parameter jumlah populasi $(\mathrm{N})$ sebanyak 150,300 dan 450 pada setiap percobaan.

b. Perbandingan total jarak berdasarkan parameter Pc yaitu 0.8 dan 0.9 pada setiap percobaan. Penggunaan nilai parameter tersebut berdasarkan nilai probabilitas crossover yang disarankan yaitu berkisar antara $80 \%$ - $95 \%$ [17].

c. Perbandingan profit yang diperoleh berdasarkan parameter Pm yaitu 0,05 dan 0,1 pada pada setiap percobaan. Penggunaan nilai parameter tersebut berdasarkan nilai probabilitas mutasi yang disarankan antara $0.5 \%-1 \%$ [17].

\section{B. Hasil Uji Coba}

Hasil terbaik didapatkan ketika implementasi kombinasi algoritma genetika dan tabu search di lakukan. Masing masing metode memeiliki hasil terbaik berdasarkan sekenario yang telah di tetapkan. Namun ketika dilakukan perbandingan implementasi metode kombinasi algoritma genetika dan tabu search mendapatkan hasil yang lebih optimal dibandingkan menggunakan algoritma genetika saja. Berikut adalah sekernario dan hasil perbandingan masing-masing metode

Tabel 1. Hasil Uji Coba Parameter

\begin{tabular}{ccccc}
\hline \hline Metode & Pc & Pm & N & Profit (Rp) \\
\hline GA & 0.9 & 0.05 & 150 & $16,092,866,667$ \\
GA-TS & 0.8 & 0.1 & 450 & $26,133,216,667$ \\
\hline \hline
\end{tabular}

\section{Analisis Hasil Uji Coba Algoritma Genetika}

Berdasarkan hasil percobaan implementasi algoritma gentika menggunakan parameter yang telah diperoleh pada Tabel 1 diperoleh hasil seperti pada Tabel 2 dan Tabel 3.

Tabel 2. GA Profit

Tabel 3. Load Factor hasil GA

\begin{tabular}{ccc}
\hline \hline Min Load Factor & Max Load Factor & $\begin{array}{c}\text { Rata-Rata Load } \\
\text { Factor }\end{array}$ \\
\hline $4 \%$ & $100 \%$ & $72 \%$ \\
\hline \hline
\end{tabular}

D. Analisis Hasil Uji Coba Kombinasi Algoritma Genetika dan Tabu Search

Berdasarkan hasil menggunakan parameter yang telah diperoleh pada Tabel 1 percobaan implementasi algoritma gentika dan tabu seacrh diperoleh hasil seperti pada Tabel 4 dan Tabel 5

Tabel 4. GA-TS Profit

\begin{tabular}{|c|c|c|c|}
\hline $\begin{array}{l}\text { Total Aktual } \\
\text { Profit (Rp) }\end{array}$ & $\begin{array}{c}\text { Total } \\
\text { Opportunity } \\
\text { Cost }(\mathrm{Rp})\end{array}$ & $\begin{array}{c}\text { Total Net Profit } \\
(\mathrm{Rp})\end{array}$ & $\begin{array}{c}\text { Waktu } \\
\text { Komputasi } \\
\text { (detik) }\end{array}$ \\
\hline $29,828,833,333$ & $5,080,233,333$ & $24,748,600,000$ & 666 \\
\hline \multicolumn{4}{|c|}{ Tabel 5. Load Factor hasil GA-TS } \\
\hline Min Load Factor & \multicolumn{2}{|c|}{ Max Load Factor } & $\begin{array}{l}\text { Rata-Rata Load } \\
\text { Factor }\end{array}$ \\
\hline $62 \%$ & \multicolumn{2}{|c|}{$99 \%$} & $86 \%$ \\
\hline
\end{tabular}

E. Perbandingan Hasil Algoritma Genetika dengan Algoritma Genetika dan Pencarian Tabu

Setelah melakukan analisis dari kedua implementasi metode GA dan GA-TS dengan melakukan uji coba parameter terbaik dan melakukan uji coba lagi dengan melakukan running sebanyak sepuluh kali menggunakan parameter yang telah di tetapkan sebagai paramenter terbaik. Selanjutnya dapat dilakukan perbandingan dari hasil kedua algoritma tersebut untuk mengetahui keuntungan atau profit dan load factor yang optimal. Hasil perbandingan profit dapat dilihat pada Tabel 6 dan hasil perbandingan load factor dapat dilihat pada Tabel 7. 
Tabel 6. Perbandingan Profit GA \& GA-TS

\begin{tabular}{cccc}
\hline \hline Metode & $\begin{array}{c}\text { Total Aktual } \\
\text { Profit (Rp) }\end{array}$ & $\begin{array}{c}\text { Total } \\
\text { Opportunity } \\
\text { Cost (Rp) }\end{array}$ & $\begin{array}{c}\text { Total Net Profit } \\
\text { (Rp) }\end{array}$ \\
\hline GA & $25,620,100,000$ & $10,936,100,000$ & $14,684,000,000$ \\
GA-TS & $29,828,833,333$ & $5,080,233,333$ & $24,748,600,000$ \\
\hline \hline
\end{tabular}

Tabel 7. Perbandingan Load Factor GA dan GA-TS

\begin{tabular}{cccc}
\hline \hline Metode & $\begin{array}{c}\text { Min Load } \\
\text { Factor }\end{array}$ & $\begin{array}{c}\text { Max Load } \\
\text { Factor }\end{array}$ & $\begin{array}{c}\text { Rata-Rata } \\
\text { Load Factor }\end{array}$ \\
\hline GA & $4 \%$ & $100 \%$ & $72 \%$ \\
GA-TS & $62 \%$ & $99 \%$ & $86 \%$ \\
\hline \hline
\end{tabular}

F. Perbandingan Hasil Algoritma Genetika dengan Algoritma Genetika dan Pencarian Tabu

Pada tahap perbandingan sebelum dan sesudah implementasi GA-TS dilakukan perhitungan pada data yang diperoleh dari perusahaan dan hasil terbaik dari GA-TS. Setelah di lakukan perhitungan untuk total actual cost, total opportunity cost, dan total profit yang diperoleh perusahaan sebelum dan sesudah implementasi GA-TS dapat di lihat perbandingan profit dan perbandingan load factor pada Tabel 8.

Tabel 8. Perbandingan Sbelum dan Sesudah Optimasi

\begin{tabular}{|c|c|c|c|}
\hline Perbandingan & $\begin{array}{c}\text { Total Aktual } \\
\text { Profit (Rp) }\end{array}$ & $\begin{array}{c}\text { Total } \\
\text { Opportunity } \\
\text { Cost (Rp) }\end{array}$ & $\begin{array}{l}\text { Total Net } \\
\text { Profit (Rp) }\end{array}$ \\
\hline $\begin{array}{c}\text { Sebelum } \\
\text { penerapan } \\
\text { metode GA-TS }\end{array}$ & $25,382,600,000$ & $19,038,333,333$ & $6,344,266,666$ \\
\hline $\begin{array}{c}\text { Sesudah } \\
\text { penerapan } \\
\text { metode GA-TS }\end{array}$ & $29,828,833,333$ & $5,080,233,333$ & $24,748,600,000$ \\
\hline Perbandingan & $\begin{array}{l}\text { Min Load } \\
\text { Factor }\end{array}$ & $\begin{array}{l}\text { Max Load } \\
\text { Factor }\end{array}$ & $\begin{array}{c}\text { Rata-Rata Load } \\
\text { Factor }\end{array}$ \\
\hline $\begin{array}{c}\text { Sebelum } \\
\text { penerapan } \\
\text { metode GA-TS }\end{array}$ & $27 \%$ & $64 \%$ & $48 \%$ \\
\hline $\begin{array}{c}\text { Sesudah } \\
\text { penerapan } \\
\text { metode GA-TS }\end{array}$ & $62 \%$ & $99 \%$ & $86 \%$ \\
\hline
\end{tabular}

\section{KESIMPULAN}

Adapun beberapa hal yang dapat disimpulkan dalam pengerjaan Studi ini adalah sebagai berikut:

1. Optimasi alokasi kapal dilakukan untuk memperoleh keuntungan yang optimal bagi pihak pengirim atau pihak perusahaan pelayaran dengan memaksimalkan muatan yang dibawa. Penerapan metode algoritma genetika dan tabu search memberikan hasil yang optimal dengan total keuntungan atau profit yang dieroleh perusahaan sebelum implementasi adalah Rp 6,344,266,666.67 dan sesudah implementasi GA-TS adalah Rp $24,748,600,000.00$. Selain itu load factor yang dihasilkan dari perhitungan data perusahaan yaitu $48 \%$ dan berdasarkan penerapan GA-TS load factor meningkat menjadi $86 \%$. Sehingga dapat disimpulkan bahwa metode GA-TS memberikan peningkatan dan dapat mengoptimalkan profit serta muatan yang harus dibawa dalam proses pengiriman barang atau container.

2. Pemilihan jumlah populasi, nilai probabilitas pindah silang dan nilai probabilitas mutasi memiliki peran penting dalam melakukan optimasi menggunakan metode algoritma genetika. Jumlah populasi $(\mathrm{N})$ yang dapat memberikan hasil paling optimal pada permasalahan optimasi alokasi kapal adalah 450 di antara jumlah populasi yang digunakan yaitu 150, 300 dan 450 . Sedangkan nilai probabilitas pindah silang $(\mathrm{Pc})$ dan nilai probabilitas mutasi $(\mathrm{Pm})$ yang dapat memberikan hasil paling optimal pada permasalahan optimasi alokasi kapal adalah 0.8 dan 0.1 .

3. Mengkombinasikan algoritma genetika dengan tabu search memberikan hasil yang paling optimal dibandingkan menggunakan algoritma genetika saja. Hal ini ditunjukkan dengan adanya peningkatan profit sebesar $69 \%$ dan peningkatan load factor sebesar $14 \%$ pada saat menggunakan GA-TS dibandingkan ketika menggunakan GA saja.

4. Waktu komputasi yang di butuhkan pada saat melakukan running GA-TS lebih lama yaitu $666 \mathrm{~s}$ dibandingkan waktu yang dibutuhkan untuk melakukan running GA yaitu $115.323 \mathrm{~s}$. Hal ini disebabkan karena pada setiap iterasi solusi yang akan dievaluasi akan dicocokkan terlebih dahulu dengan isi tabu list, dimana tabu list memiliki jumlah yang cukup banyak sesuai dengan jumlah pergerakan dari solusi yang ada.

\section{DAFTAR PUSTAKA}

[1] G. Garai and B. B. Chaudhurii, "A novel hybrid genetic algorithm with Tabu search for optimizing multi-dimensional functions and point pattern recognition," Inf. Sci., vol. 221, pp. 28-48, Feb. 2013 [Online]. Available:

http://linkinghub.elsevier.com/retrieve/pii/S0020025512006056. [Accessed: 05-Oct-2016]

[2] D.-Y. Lin and H.-Y. Liu, "Combined ship allocation, routing and freight assignment in tramp shipping," Transp. Res. Part E Logist. Transp. Rev., vol. 47, no. 4, pp. 414-431, Jul. 2011 [Online]. Available: http://linkinghub.elsevier.com/retrieve/pii/S1366554510001237. [Accessed: 05-Oct-2016]

[3] K. Setemen, "Implementasi Algoritma Genetika dalam Pengembangan Sistem Aplikasi Penjadwalan Kuliah," J. IKA, vol. 8, no. 1, 2010 [Online].

http://ejournal.undiksha.ac.id/index.php/IKA/article/view/156. [Accessed: 05-Oct-2016]

[4] E. Suhartono, "OPTIMASI PENJADWALAN MATA KULIAH DENGAN ALGORITMA GENETIKA (Studi Kasus di AMIK JTC Semarang)," INFOKAM, vol. 11, no. 5, 2015 [Online]. Available: http://jurnal.amikjtc.com/index.php/jurnal/article/view/86. [Accessed: 30-Sep-2016]

[5] Marwana, "Optimasi Penjadwalan Mata Kuliah Menggunakan Algoritma Genetika Berbasis Permintaan MahasiswaO," Pros. Konf. Nas. Ilmu Komput. 2012, 2012.

[6] A. O. Adewumi and M. M. Ali, "A multi-level genetic algorithm for a multi-stage space allocation problem," Math. Comput. Model., vol. 51, no. 1-2, pp. 109-126, Jan. 2010 [Online]. Available: http://linkinghub.elsevier.com/retrieve/pii/S0895717709003306. [Accessed: 30-Sep-2016] 
[7] S. Anwar, "Mengenal jasa transportasi laut dan udara," J. Transp. 112 $20101-9,2010$.

[8] D. Ronen, "Cargo ships routing and scheduling: Survey of models and problems," Eur. J. Oper. Res., vol. 12, no. 2, pp. 119-126, 1983 [Online]. Available: http://www.sciencedirect.com/science/article/pii/0377221783902151. [Accessed: 01-Oct-2016]

[9] F. Valentito, "Optimasi Skenario Bunkering dan Kecepatan Kapal pada Pelayaran Tramper," J. Tek. POMITS Vol 1 No 12012 1-5.

[10] X. Heli, Y. Shanshan, and Lijia, "The Application of Genetic Algorithm Based on Multi-dimension Code Scheme on Course Scheduling In Adult Education," Proc. Third Int. Symp. Electron. Commer. Secur. Work. '10 Guangzhou P R China 29-31July 2010 Pp 005-009, 2010.

[11] D. Hermawanto, "Algoritma Genetika dan contoh aplikasinya," Retrieved, vol. 10, no. 25, p. 2013, 2003 [Online]. Available: http://www.academia.edu/download/33039788/algoritma_genetika_dan contoh_aplikasinya_-_denny_hermawanto.pdf. [Accessed: 30-Sep-2016]

[12] M. Hanita, "Penerapan Algoritma Genetika pada Penjadwalan Mata Kuliah (Studi Kasus: Program Studi Matematika FMIPA Universitas Bengkulu)," Non Publ. Univ. Bengkulu, 2011.

[13] L. Spector, "Autoconstructive evolution: Push, pushGP, and pushpop," in Proceedings of the Genetic and Evolutionary Computation Conference (GECCO-2001), 2001, vol. 137 [Online]. Available: http://luisamark.com/mark/ou/docs/ace.pdf. [Accessed: 01-Oct-2016]

[14] W. Hartono, "OPTIMASI ALOKASI SUMBER DAYA DENGAN GENETIC ALGORITHMS," Media Tek. Sipil, vol. 11, no. 2, pp. 108114, $2016 \quad$ [Online]. Available: http://media.sipil.ft.uns.ac.id/index.php/mts/article/view/132. [Accessed: 30-Sep-2016]

[15] B. Santosa and P. Willy, Metoda Metaheuristik Konsep dan implementasi. Prima printing, Surabaya, 2011.

[16] H. M. Sitorus, C. P. Sitorus, and P. Ciputra, "Penerapan Algoritma Tabu Search Pada Permasalahan Lintasan Keseimbangan Bentuk U Tipe I Dengan Waktu Proses Stokastik," Ind. Syst. Eng. Assess. J. INASEA, vol. 15, no. 1, 2014 [Online]. Available: http://journal.binus.ac.id/index.php/inasea/article/view/238. [Accessed: 02-Jan-2017] 